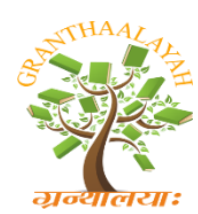

$$
\begin{gathered}
\text { INTERNATIONAL JOURNAL OF RESEARCH - } \\
\text { GRANTHAALAYAH } \\
\text { A knowledge Repository }
\end{gathered}
$$

Management

\title{
AN EXAMINATION OF THE ANTECEDENTS OF CUSTOMER SATISFACTION, BEHAVIORAL RESPONSE AND INTENTIONS AMONG RETAIL STORE FORMATS
}

\author{
Dr. Pankaj Kumar *1 \\ ${ }^{*}$ Assistant Professor, Department of Management Studies, Deenbandhu Chhotu Ram University \\ of Science \& Technology, Murthal, Sonipat, Haryana, India
}

DOI: https://doi.org/10.29121/granthaalayah.v5.i1.2017.1887

\begin{abstract}
The purpose of this study is to examine the effect of store image attributes, customer attitude and perceived value on consumers' satisfaction, behavioral response and intentions and also, the effect of customer satisfaction on behavioral response and loyalty intentions. A structured questionnaire was successfully distributed to 600 respondents, who had made purchases from sixty retail formats operated in Delhi and Gurugram belonging to the domain of Shopping Malls, Hypermarket, Supermarket, Department Stores, Discount stores and Category Killers through systematic stratified sampling for the collection of data. Factor analysis was employed to identify the store image attributes as perceived by retail customers. Multiple regression analysis was conducted to predict customers' satisfaction, behavioral response (word of mouth communication), intention to switch, and customers' loyalty intention from retail store image attributes, customers' overall store attitude and perceived customer value, and to predict behavioral response and intentions from customers' satisfaction. The results of the study showed that customers' overall store attitude and perceived customer value are significant for all the dependent variables (customers' satisfaction, behavioral response (word of mouth communication), intention to switch, and customers' loyalty intention), while store image is partially influencing customers' satisfaction, behavioral response and intentions, furthermore customer satisfaction is significant predictors of customers' behavioral response and intentions. The implications for marketers and managers have also discussed.
\end{abstract}

Keywords: Store Image; Customer Attitude; Perceived Value; Customer Satisfaction; Behavioral Response; Loyalty Intention Intentions.

Cite This Article: Dr. Pankaj Kumar. (2017). “AN EXAMINATION OF THE ANTECEDENTS OF CUSTOMER SATISFACTION, BEHAVIORAL RESPONSE AND INTENTIONS AMONG RETAIL STORE FORMATS." International Journal of Research Granthaalayah, 5(1), 239-257. https://doi.org/10.29121/granthaalayah.v5.i1.2017.1887. 


\section{Introduction}

The image of a store in customer's mind is extremely important and concerned with the present $\&$ future behaviour of retail customers, moreover its increase customers' frequency for buying and also gain new customers, if retail store is able to introduce itself to customers through creating true image will lead to sales and profitability of retailers. Retailers should always tried to create a positive image in customers' mind by knowing about those attributes which form the image of a store and use them in a right manner, so that store image attributes positively affect customer satisfaction (Brunner et al., 2008; Theodoridis and Chatzipanagiotou, 2009; Helgesen et al., 2010). Now the question arise that why to study store image, customer attitude, perceived customer value, customer satisfaction, behavioral response and intentions in a linking manner. As the answer, author argue that store image, customer overall store attitude, perceived customer value, customer satisfaction and subsequently store loyalty have gained great importance in the retail stores settings, which aim to survive in the market and store image is a key factor for influencing customer satisfaction (Bluemer and Ruyter, 1998; Koo, 2003) and also affects positively on customer patronage intentions (Chang and $\mathrm{Tu}, 2005$ ), moreover the role of store image for attracting and retaining the customers becomes extremely important (Du Preez et al., 2008). Researchers have pointed out the need for a comprehensive scale to measure store image with customer attitude and perceived value, and their impact on customer satisfaction and loyalty because it was deficient in research (Du Preez et al., 2008). After the reviewing of existing literature, it is found that most of the studies on retail sector are reported from developed countries and no studies were identified that evaluate the impact of store image attributes, customer attitude and perceived customer value on customer satisfaction, behavioral response and intentions collectively in Indian retail store settings. Thus, the validity of theories and previous findings on customer satisfaction and loyalty behaviour needs to be tested in different economy and socio cultural environment in order to assess their universal applicability, so the present study aims to fill in this gap and the findings of this study will be of interest with existing and would-be multinational and domestic retailers of organised retail sector in India.

The conceptualisation of store image has started to gain the recognition in retailing from last thirty years (Lindquist, 1974; James et al., 1976). The concept of store image has been defined by many researchers by diversified way at different point of time, firstly Martineau (1958) defined store image as the personality of retail store composed of functional and psychological attributes and indicated that layout of store, symbols and colors, commercials and sales personnel are the important factors which create store image. Later on in 1974, Doyle and Fenwick defined the store image as "evaluation of all relevant features of a store as perceived and weighted individually" and the retail store image is represented by a multi-attribute construct (James et al., 1976; Marks, 1976), furthermore Morschett et al. (2005) described that there is no common, well-known and acceptable definition of store image exist till date, reason being the gap between the various ways of its conceptualisation and operations and the focus has predominantly been on the relationships among attributes which constituting the retail image and their representation. Zeithaml (1988) defined Perceived value as customer's overall assessment of product utility based on perceptions of what has received and what is given. Sweeney and Soutar (2001) developed a scale to measure perceived value in multi-dimensions aspects called (PERVAL scale) having six items of quality, four items of price as "functional value referred to as product performance", five items of "emotional value as affective feelings generated by a product", and 
four items of "social value as the utility derived from the product's ability to enhance the consumer's social self-concept", and as results study indicated that multi-dimensional scale performed better than a single value item such as value for money, when explaining customer choices. On the other side customer satisfaction is related with various positive outcomes which include creating and increased market share and profitability of firms purchase intention of customers, customer retention and loyalty (Cronin and Taylor, 1992; Anderson et al., 1994; Zeithaml, 2000). Customer satisfaction is a function of the difference between a customer's expectations prior to purchase and their perception of the same product and service after purchase (Oliver, 1980; Anderson and Sullivan, 1993), while Tse and Wilton (1988) evident that satisfaction is a general psychological phenomenon, describing the emotional state resulting from an evaluation of the perceived discrepancy between prior expectations and actual performance of the product or service. The overall customer satisfaction has three antecedents: perceived quality, perceived value, and customer expectations (Fornell et al., 1996). Day (1969) defined loyalty as a favourable attitude of a customer towards a brand in addition to purchase it repetitively. Loyalty discussed as 'behavioral response expressed over time' which includes frequency of future purchasing, world-of-mouth communication and pay price premium (Dick and Basu, 1994; Olsen, 2002; Tuu et al., 2011).

\section{Review of Literature}

At different point of time various researchers have expressed store image in diversified form, Lindquist (1974) did a study on the availiable literature on store image and designed nine elements of store image such as merchandise, physical facilities, store atmosphere, comfort, services, clientele, promotion, institutional and post-transactional satisfaction, while location, product, price, assortment and styling are the five elements of store image recognized by (Doyle and Fenwick, 1974) and service, price, product, convenience, atmosphere, and promotion, suggest by (Theodoridis and Chatzipanagiotou, 2009), moreover product (quality, price, and diversity), store atmosphere, store facilities, store service (sales personnel service and loan service), store brand, facilities (ease of shopping, transportation) and promotion were considered as major attributes of store image by (Yoo and Chang, 2005; Fazlzadeh et. al., 2012). After reviewing of literature, the main concern as how many attributes related to store image will effect significantly on customer satisfaction, behavioral response and intentions. Regarding this various researchers have numbers of responses as, Juhl et al. (2002) did a study on five European countries: France, Denmark, Finland, Portugal and Switzerland for the investigation of degree of customer satisfaction in food retailing and found that product quality is the most prominent factor of store image and satisfaction, moreover product assortment, store atmosphere, price, service has a clear influence on the store image and customer satisfaction (Baker et al., 2002), Furthermore product assortment was the single most significant variable affecting the store image, customer satisfaction and choice of retail format across hypermarkets, supermarkets, conventional store and discount stores (Carpenter and Moore, 2006) and apparel stores (Anselmsson, 2006). Price is found most important store image attribute for customers to decide where to shop (Desai and Talukdar, 2003), and price levels of products have been also found to be a significant reason to determine the choice of retail format across different customer groups (Baltas and Papastathopoulou, 2003; Carpenter and Moore, 2006), but Fox et al. (2004) specified that the US consumers are not sensitive about the price in buying from stores and reason may be as US is developed country with high level of education, income and living standard, but in India 
the consumers are price sensitive. Regarding other important aspects of store image and customer satisfaction perceived crowding store and waiting time have negative impact (Eroglu et al., 2005; Bielen and Demoulin, 2007), whereas physical evidence or facilities (Groeppel-Klein and Germelmann, 2003), promotion factors (Carroll et al., 2007), sales personnel (Darian et al., 2001), and store design \& ease factors have been found significant toward store image and customer satisfaction (Turhan, 2014). Loyalty is the combination of intention to repurchase, willingness to pay more and positive word-of-mouth communication (Cronin and Taylor, 1992; Zeithaml et al., 1996; Yoon et al., 2010). The attitudinal loyalty intentions consist repurchase intention, demonstrating resistance to switch to the competitors Cronin and Taylor, 1992), whereas behavioral loyalty includes positive word-of-mouth communication and willingness to recommend to others (Andreassen and Lindestad, 1998; Rauyruen and Miller, 2007). Watanabe et al. (2013) tested the relationship between image attributes and consumer satisfaction in the context of supermarkets to measure the impact of store image attributes on consumer satisfaction and found that the constructs such as "environment" and "promotions" were not considered significant in determining consumer satisfaction, while the constructs such as "personnel", "product" and "prices" were found to be significant, earlier Naderian (2012) investigated store image attributes effect on customer satisfaction and concluded that merchandise has the most significant effect on customer satisfaction followed by price, personnel and atmosphere respectively. Demirgunes (2014) examined the various studies on antecedents of store image and customer satisfaction and concluded that most of the studies show the result as prominence and positive relationship between store image and customer satisfaction towards the store. This study also revealed that retail stores should always tried to harmonies store image and personnel characteristics of retail customers because demographics and socioeconomic factors can explain that what customers expect from store, moreover store image is indirectly influence and customer satisfaction is directly influence loyalty towards store.

\subsection{Store Image, Customer Attitude, Perceived Value, Customer Satisfaction, Behavioral Response and Intentions-A Linkage}

A number of studies have been undertaken in the direction of store image, customer attitude and perceived customer value and their effect on customer Satisfaction, behavioral response and intentions toward retail stores and indicate that store image has a significant effect on the customer's preference of the store, satisfaction with the store (Samli et al., 1998; Chang and Tu, 2005; Chang and Fong, 2010), and loyalty to store (Bloemer and Odekerken-Schroder, 2002), furthermore customer satisfaction is a primary guide to store loyalty (Caruana et al., 2000; Pan and Zinkhan, 2006), but Copeland (1923) was the first one among all researchers, who studied store image, satisfaction, loyalty concepts together and explained that before arriving at the phase of customer satisfaction, the effective use of attributes which are used for store image formation and thus a positive image created in the customer's mind are associated with customer satisfaction and satisfaction is associated with loyalty towards store. The relationship between customer attitude and behavioral intentions has been extensively examined and supported empirically (Dick and Basu 1994) and suggested that low relative attitude with low repeat purchase brings absence of loyalty, while low relative attitude with high repeat purchase indicates dissolute loyalty and perceived value not only affects customer choice behavior at the pre-purchase stage, but also influences satisfaction and intentions to recommend and repurchase at the post purchase stage (Parasuraman \& Grewal, 2000) and Perceived value has been 
considered to be a major determinant of customer satisfaction (McDougall and Levesque, 2000). Thomas (2013) proposed and validated a structural model linking customer loyalty to customer satisfaction and store image and found that store image was seen to have a positive impact on customer loyalty through the customer satisfaction as mediating variable.

\subsection{Conceptual Formation}

Based on the reviewed of marketing literature on store image, customer attitude, perceived customer value, customer satisfaction and customer loyalty behaviour the conceptual framework of this study preliminary consisted of two sections: the first section concerning with store image attributes as perceived by the customers, customer attitude and perceived customer value towards various retail formats (Shopping Malls, Hypermarket, Supermarket, Department Stores, Discount stores and Category Killers). In this section store image was categorized in fourteen dimensions namely "merchandise contains three items", "service contains four items", "shopping atmosphere contains four items", "pricing contains four items", "product innovation contains three items", "sales personnel competence contains seven items", "reliability contains six items", "physical evidence contains eleven items", "convenience contains four items", "location contains four items", "after sale services contains four items", "product availability contains three items", "crowding contains two items", and "peripheral services contains two items", beside this "customer attitude towards store contains three items" and perceived customer value was categorized in three dimensions namely "symbolic value contains three items", "financial value contains two items" and, "overall value contains one item". The second part of study includes "customers' satisfaction contains three items" and customer loyalty towards retail formats. In the study customer loyalty was comprised of three aspects: “customers' behavioral response (wordof-mouth communication) contains three items", "customers' intention to switch contains four items" and "customers' loyalty intention contains four items". The main emphasis of the present study is to investigate the effect of store image attribute, customer attitude and perceived customer value on consumer satisfaction, behavioral response and intentions, and also, the effect of customer satisfaction on behavioral response and loyalty intentions. Confirming the reviewed findings of prior researches, the following hypotheses were developed.

$\mathbf{H}_{1}$ : There is significant effect of store image on retail customers' satisfaction.

$\mathbf{H}_{2}$ : There is significant effect of overall store attitude on retail customers' satisfaction.

$\mathbf{H}_{3}$ : There is significant effect of perceived value on retail customers' satisfaction.

$\mathbf{H}_{4}$ : There is significant effect of store image on retail customers' behavioral response (word of mouth communication).

H5: There is significant effect of overall store attitude on retail customers' behavioral response (word of mouth communication).

$\mathbf{H}_{6}$ : There is significant effect of perceived value on retail customers' behavioral response (word of mouth communication).

$\mathbf{H}_{7}$ : There is significant effect of store image on retail customers' intention to switch. 
H8: There is significant effect of overall store attitude on retail customers' intention to switch.

$\mathbf{H}_{9}$ : There is significant effect of perceived value on retail customers' intention to switch.

$\mathbf{H}_{10}$ : There is significant effect of store image on retail customers' loyalty intention.

$\mathbf{H}_{11}$ : There is significant effect of overall store attitude on retail customers' loyalty intention.

$\mathbf{H}_{12}$ : There is significant effect of perceived value on retail customers' loyalty intention.

$\mathbf{H}_{13}$ : There is significant effect of customer satisfaction on retail customers' behavioral response (word of mouth communication).

$\mathbf{H}_{14}$ : There is significant effect of customer satisfaction on retail customers' intention to switch.

$\mathbf{H}_{15}$ : There is significant effect of customer satisfaction on retail customers' loyalty intention.

\section{Materials and Methods}

The purpose of the study is to examine the effect of store image attribute, customer attitude and perceived customer value on consumer satisfaction, behavioral response and intentions and second, the effect of customer satisfaction on behavioral response and loyalty intentions. A structured questionnaire was successfully distributed to 600 respondents, who had made purchases from sixty retail formats operated in Delhi and Gurugram belonging to the domain of Shopping Malls, Hypermarket, Supermarket, Department Stores, Discount stores and Category Killers through systematic stratified sampling for the collection of data, reason being Delhi and Gurugram as the area has a high migrated and heterogeneous residents with various dimensions such as religious, caste, traditions, social hierarchy, language, literacy, education, occupation and income etc. Out of 600 distributed questionnaires, 461 questionnaires were filled by respondents, 84 incomplete questionnaires were not used for analysis and 377 questionnaires were valid ones; thus the effective recovery rate was 62.83 per cent and respondents were personally administered. The five-point Likert Scale was used to with 1 indicating "strongly disagree" and 5 indicating "strongly agree" examining the store image attributes, customer attitude, perceived value, customers' satisfaction, behavioral response and intentions towards retail store formats. SPSS (Version17.0) was used for analysis in this study. Internal consistency analysis was used to access the reliability of measurements. Cronbach's $\alpha$-value is commonly used for this purpose and $\alpha$-value must be higher than 0.70 (Nunnally, 1978). Factor analysis was used to determine how many factors related to dimensions of store image as perceived by customers towards retail formats were being measured by the instrument. Multiple regression analysis with forward selection was employed to predict customers' satisfaction, behavioral response (word of mouth communication), intention to switch, and customers' loyalty intention from retail store image, customers' overall store attitude and perceived customer value, and second, behavioral response and intentions from the customers' satisfaction. 


\subsection{Internal Consistency Analysis}

Internal consistency was used to assess the reliability of the measurements (seven constructs) depicting the degree to which they indicate a common latent (unobserved) construct. The value of each variable, as measured by each statement on the five-point Likert scale, was computed using the reliability analysis procedure. Description of the variables (V1 to V7) those used in the study are shown in table-1.

Table 1: Internal Consistency Analysis of the Store Image, Customer Attitude, Perceived Customer Value, Customers' Satisfaction, Behavioral Response and Intentions

\begin{tabular}{|l|l|l|l|}
\hline Variable No. & \multicolumn{1}{|c|}{ Description } & \multicolumn{1}{c|}{$\begin{array}{c}\text { No. of } \\
\text { items/statements }\end{array}$} & $\begin{array}{c}\text { Cronbach's } \\
\text { Alpha }\end{array}$ \\
\hline $\mathrm{V}_{1}$ & Store Image & 61 & 0.8243 \\
\hline $\mathrm{V}_{2}$ & Customer Attitude & 03 & 0.8736 \\
\hline $\mathrm{V}_{3}$ & Perceived Customer Value & 06 & 0.7528 \\
\hline $\mathrm{V}_{4}$ & Customer Satisfaction & 03 & 0.8942 \\
\hline $\mathrm{V}_{5}$ & Word-of-mouth communication & 03 & 0.8719 \\
\hline $\mathrm{V}_{6}$ & Intention to switch & 04 & 0.8238 \\
\hline $\mathrm{V}_{7}$ & Loyalty intentions & 04 & 0.8407 \\
\hline
\end{tabular}

The alpha values range from 0.7528 to 0.8942 , which indicates an internal consistency with the alpha value of more than 0.70 , so no items were dropped from above list. These results are therefore acceptable and are a reliable measure of the constructs. Overall, this section of the instrument has been proven to be an acceptable instrument through this test.

\subsection{Descriptive Statistic}

Table- 2 shows that from a total of 377 respondents, the representation was noted higher of male respondents (54.11 per cent), who were married (35.81 per cent), Bachelor degree (22.81 per cent), in the age group of 25-35 years ( 26 per cent) and 36-45 years (15.12 per cent), belonging to salaried class (28.65 per cent) and earn more than Rupees 10 lakhs (22.55 per cent) being surveyed from the premises of malls (11.94 per cent), department Stores (5.57 per cent), discount Stores (8.49 per cent) and category Killer Stores (11.41 per cent) as compared to their female counterparts under study. On the other side, female representation was slightly higher of those holding master degree or above (25.20 per cent), within an annual income group of Rupees 5-10 lakhs (18.04 per cent) and who participated from the premises of Hypermarkets (10.34 per cent) or Supermarkets ( 9.55 per cent) in the survey. 
Table 2: Retail Formats-wise Distribution of Surveyed Customers and their Demographic Profile

\begin{tabular}{|c|c|c|c|c|}
\hline \multirow{2}{*}{\multicolumn{2}{|c|}{ Basic Classification }} & \multicolumn{3}{|c|}{ Numbers of Respondents (Percentage) } \\
\hline & & \multirow{2}{*}{$\begin{array}{l}\text { Male } \\
45(11.94)\end{array}$} & \multirow{2}{*}{$\begin{array}{l}\text { Female } \\
34(9.01)\end{array}$} & \multirow{2}{*}{$\begin{array}{l}\text { Total }(\mathbf{N}=\mathbf{3 7 7}) \\
79(20.95)\end{array}$} \\
\hline \multirow{6}{*}{$\begin{array}{l}\text { Formats of } \\
\text { Retail Store }\end{array}$} & Malls & & & \\
\hline & Hypermarket & $33(8.75)$ & 39 (10.34) & $72(19.10)$ \\
\hline & Supermarket & $30(7.96)$ & $36(9.55)$ & $66(17.51)$ \\
\hline & Department Store & $21(5.57)$ & $19(5.04)$ & $40(10.61)$ \\
\hline & Discount Store & $32(8.49)$ & $15(3.98)$ & 47 (12.47) \\
\hline & Category Killers & $43(11.41)$ & $30(7.96)$ & $73(19.36)$ \\
\hline \multirow{4}{*}{ Age } & $<25$ years & $21(5.57)$ & $23(6.10)$ & $44(11.67)$ \\
\hline & 25-35 Years & $98(26.00)$ & $65(17.24)$ & $163(43.24)$ \\
\hline & $36-45$ Years & $57(15.12)$ & $49(13.00)$ & $106(28.12)$ \\
\hline & $>45$ Years & $28(7.42)$ & $36(9.55)$ & $64(16.97)$ \\
\hline \multirow{3}{*}{$\begin{array}{l}\text { Highest Level } \\
\text { of Education }\end{array}$} & Diploma or below & $31(8.22)$ & $11(2.92)$ & $42(11.14)$ \\
\hline & Bachelor Degree & $86(22.81)$ & $67(17.80)$ & $153(40.57)$ \\
\hline & Master Degree or & $87(23.08)$ & $95(25.20)$ & $182(48.28)$ \\
\hline \multirow{2}{*}{ Marital Status } & Single & $69(18.30)$ & $56(14.85)$ & $125(33.16)$ \\
\hline & Married & $135(35.81)$ & $117(31.04)$ & $252(66.84)$ \\
\hline \multirow{4}{*}{ Occupation } & Student & $17(4.51)$ & $06(1.59)$ & $23(6.10)$ \\
\hline & Housewife & $0(0.0)$ & $18(4.77)$ & $18(4.77)$ \\
\hline & Salaried & $108(28.65)$ & $101(26.79)$ & $209(55.44)$ \\
\hline & Self-Business & $79(20.95)$ & $48(12.73)$ & $127(33.69)$ \\
\hline \multirow{3}{*}{$\begin{array}{l}\text { Annual Income } \\
\text { (In Rupees) }\end{array}$} & $<$ Rupees 5 lakhs & $52(13.79)$ & $57(15.12)$ & $109(28.91)$ \\
\hline & Rupees 5-10 lakhs & $67(17.77)$ & $68(18.04)$ & $135(35.81)$ \\
\hline & > Rupees 10 lakhs & $85(22.55)$ & $48(12.73)$ & $133(35.29)$ \\
\hline \multicolumn{2}{|l|}{ Total $(\mathrm{N}=377)$} & $204(54.11)$ & $173(45.89)$ & 377 (100) \\
\hline
\end{tabular}

Furthermore, out of 377 respondents, 20.95 per cent from the premises of Shopping Malls, 19.36 per cent from Category Killers, 19.10 per cent from Hypermarkets, 17.51 per cent from Supermarkets, 12.47 per cent from Discount Stores and 10.61 per cent from Department Stores, were the participants in the final survey. 


\section{Results and Discussions}

Using the sample of 377 responses, a factor analysis was used to analyze the data using principal component analysis as the extraction method and varimax as a technique of rotation to determine how many factors were being measured by the instrument.

Table 3: Factor Analysis of Indicators Used for Assessing Store Image as Perceived by Retail Store Customers

\begin{tabular}{|c|c|c|c|c|c|}
\hline Factors & Statements & $\begin{array}{l}\text { Factor } \\
\text { Score }\end{array}$ & $\begin{array}{l}\text { Eigen } \\
\text { values }\end{array}$ & $\begin{array}{l}\text { Variance } \\
\text { explained } \\
\text { (per cent) }\end{array}$ & $\begin{array}{l}\text { Cronbach's } \\
\text { Alpha }\end{array}$ \\
\hline \multirow{3}{*}{ Merchandise } & $\begin{array}{l}\text { Products at this store are highly } \\
\text { dependable. }\end{array}$ & 0.74 & \multirow{3}{*}{3.12} & \multirow{3}{*}{$67 \%$} & \multirow{3}{*}{0.82} \\
\hline & $\begin{array}{l}\text { Products at this store are of highly } \\
\text { quality. }\end{array}$ & 0.72 & & & \\
\hline & Products at this store are of high value. & 0.67 & & & \\
\hline \multirow{4}{*}{ Service } & $\begin{array}{l}\text { This store offers customized service to its } \\
\text { customers. }\end{array}$ & 0.68 & \multirow{4}{*}{3.16} & \multirow{4}{*}{$61 \%$} & \multirow{4}{*}{0.81} \\
\hline & $\begin{array}{l}\text { Descriptive information about the } \\
\text { products on display is provided by this } \\
\text { store. }\end{array}$ & 0.71 & & & \\
\hline & $\begin{array}{l}\text { Contacting the employees at this store is } \\
\text { easy. }\end{array}$ & 0.66 & & & \\
\hline & $\begin{array}{l}\text { This store offers convenient product } \\
\text { delivery/ shipping/ tracking facility. }\end{array}$ & 0.72 & & & \\
\hline \multirow{4}{*}{$\begin{array}{l}\text { Shopping } \\
\text { Atmosphere }\end{array}$} & $\begin{array}{l}\text { Privacy and security of customers is } \\
\text { maintained by this store. }\end{array}$ & 0.61 & \multirow{4}{*}{2.76} & \multirow{4}{*}{$63 \%$} & \multirow{4}{*}{0.78} \\
\hline & $\begin{array}{l}\text { Shopping process at this store is } \\
\text { convenient and time saving. }\end{array}$ & 0.73 & & & \\
\hline & $\begin{array}{l}\text { Merchandize display at this store is very } \\
\text { good. }\end{array}$ & 0.71 & & & \\
\hline & $\begin{array}{l}\text { This store has an easy-to-follow layout } \\
\text { for customers to find what they need. }\end{array}$ & 0.70 & & & \\
\hline \multirow{4}{*}{ Pricing } & $\begin{array}{l}\text { This store provides appropriate prices for } \\
\text { merchandize they sell. }\end{array}$ & 0.75 & \multirow{4}{*}{1.93} & \multirow{4}{*}{$58 \%$} & \multirow{4}{*}{0.73} \\
\hline & This store offers fair/competitive prices. & 0.71 & & & \\
\hline & $\begin{array}{l}\text { This store offers manufacturer coupons } \\
\text { and free samples. }\end{array}$ & 0.62 & & & \\
\hline & $\begin{array}{l}\text { This store offers lot of discounts and } \\
\text { special sales promotions. }\end{array}$ & 0.69 & & & \\
\hline \multirow{3}{*}{$\begin{array}{l}\text { Product } \\
\text { Innovation }\end{array}$} & $\begin{array}{l}\text { This store sells extensive variety of } \\
\text { products. }\end{array}$ & 0.61 & \multirow{3}{*}{2.76} & \multirow{3}{*}{$63 \%$} & \multirow{3}{*}{0.79} \\
\hline & $\begin{array}{l}\text { I find unique products available in this } \\
\text { store. }\end{array}$ & 0.72 & & & \\
\hline & I find out about new products in this store. & 0.70 & & & \\
\hline $\begin{array}{l}\text { Sales } \\
\text { Personnel } \\
\text { Competence }\end{array}$ & $\begin{array}{l}\text { Sales personnel know what my needs are } \\
\text { and how the retailer's products can satisfy } \\
\text { them. }\end{array}$ & 0.73 & 2.49 & $61 \%$ & 0.86 \\
\hline
\end{tabular}




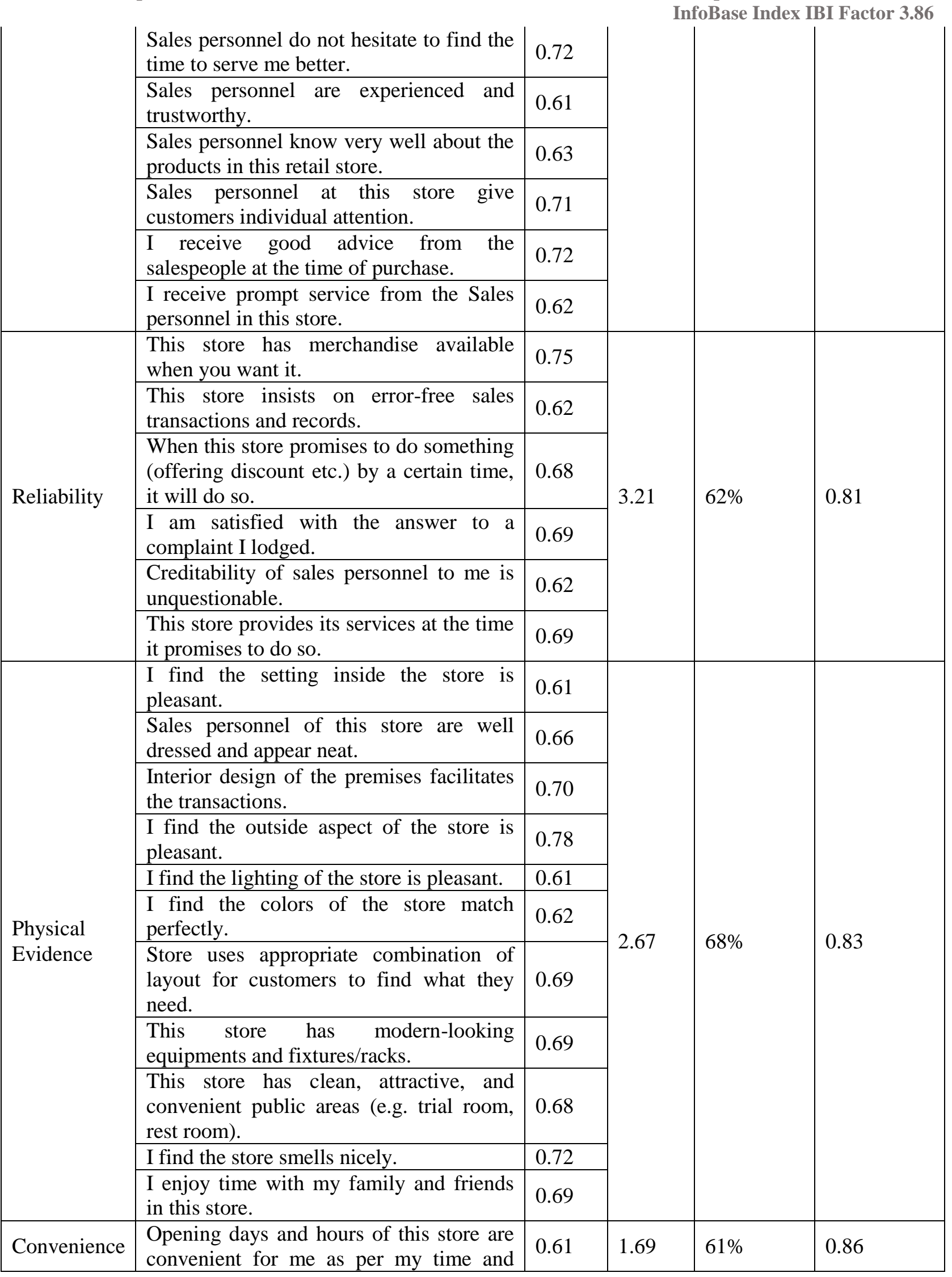




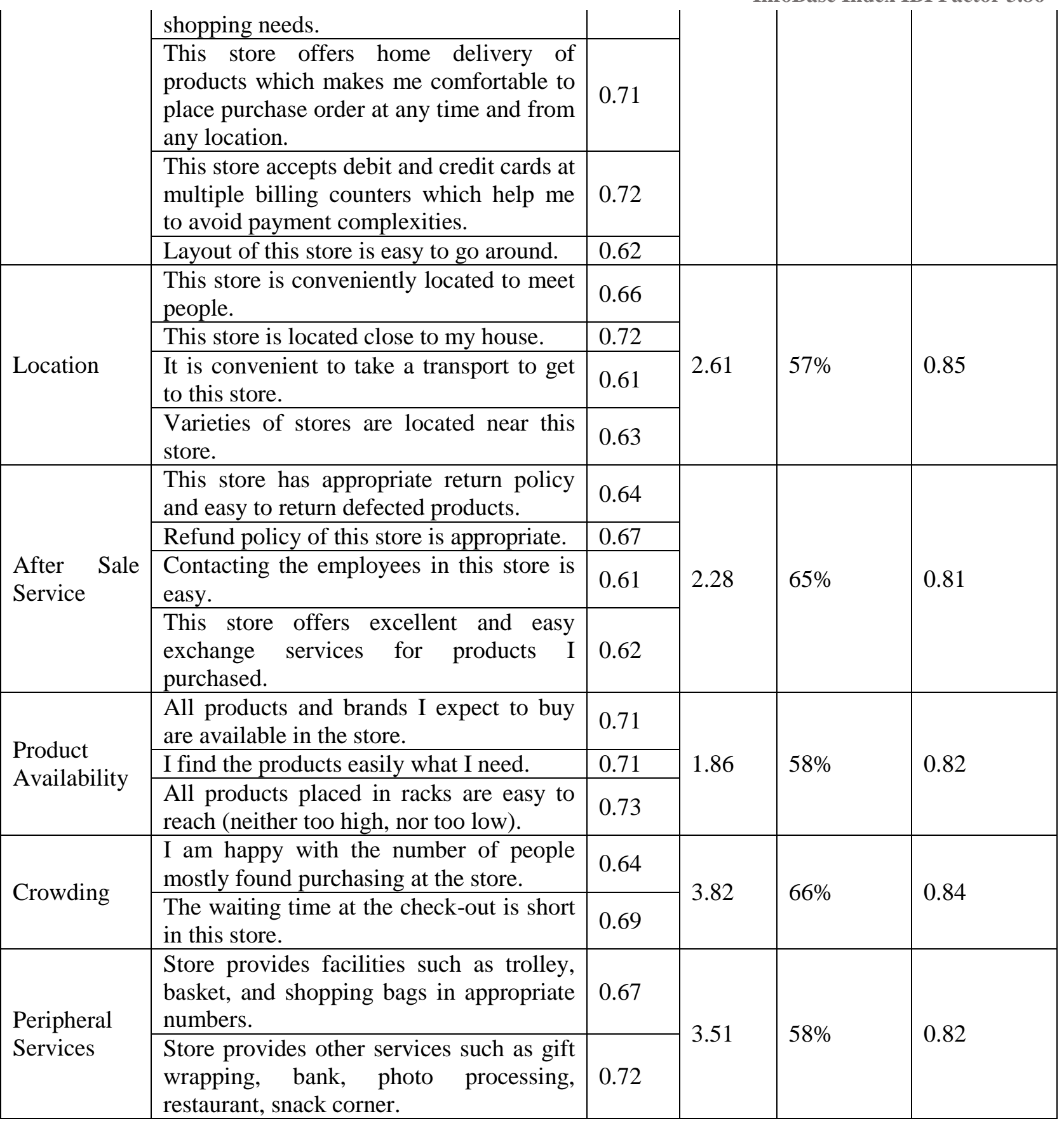

It was revealed that fourteen factors of store image account for 62 per cent of the variance in the instrument. Two of the factors that accounted for smaller amounts of variance were consolidated with other factors reducing the instrument to fourteen factors. The fourteen factors were the following: Merchandise; Service; Shopping atmosphere; Pricing; Product innovation; Sales personnel competence; Reliability; Physical evidence; Convenience; Location; After Sale Service; Product availability; Crowding; and Peripheral Services. Table-3 depicts the loading of the 61 items on each factor (for factor loading greater than .50). Moreover, the 61-item instrument had a reliability of 0.82 . The result also indicate 67 percentage of variance in 
Merchandise, 61 percentage of variance in Service, 63 percentage of variance in Shopping atmosphere, 58 percentage of variance in Pricing, 63 percentage of variance in Product innovation, 61 percentage of variance in Sales personnel competence, 62 percentage of variance in Reliability, 68 percentage of variance in Physical evidence, 61 percentage of variance in Convenience, 57 percentage of variance in Location, 65 percentage of variance in After Sale Service, 58 percentage of the variance in Product availability, 66 percentage of variance in Crowding, and 58 percentage of the variance in Peripheral Services.

\subsection{Hypotheses Testing: Multiple Regression Analysis Results of Store Image Facets on Retail Customers' Satisfaction and Behavioral Response and Intentions (Table-4).}

Four distinct multiple regression models were run to test the twelve hypotheses: four on customer attitude (one for customers' satisfaction, one for word-of-mouth communication, one for intention to switch and one for loyalty intention); four hypotheses on customer value (one for customers' satisfaction, one for word-of-mouth communication, one for intention to switch and one for loyalty intention); and four hypotheses on store image (one for customers' satisfaction, one for word-of-mouth communication, one for intention to switch and one for loyalty intention). Table-4 shows results of the first multiple regression analysis with customers' satisfaction about retail store visit as the dependent variable and the customer attitude, perceived customer value and store image as the independent variables. The overall model is significant at $\mathrm{p}<0.05$ or $\mathrm{p}<$ 0.01 . The overall model fit for regression equation was determined by F statistics. The model revealed a significant impact of customer attitude, customer value and store image entered in the model. More specifically 'customer attitude', 'customer value', and store image related factors 'shopping atmosphere', 'pricing', 'product innovation', 'sales personnel competence', 'reliability', 'physical evidence', 'convenience' and 'after sales service' accounted for 27.1 percentage $(\mathrm{R} 2=0.271)$ of variance in dependent variable of customers' satisfaction, $\mathrm{F}(16,377)$ $=8.364$, conversely, 'merchandize', 'service', 'location', 'crowding', 'product availability' and 'peripheral services' failed to show any significant relationship with customers' satisfaction. Thus, $\mathrm{H} 1$ was partially supported and $\mathrm{H} 2, \mathrm{H} 3$ were supported. Results of the second multiple regression analysis are also shown in table-4, the dependent variable was customers' behavioral response (word-of-mouth communication) about retail store and the customer attitude, customer value and store image as the independent variables. Like the first test, the overall model is significant at $\mathrm{p}<0.05$ or $\mathrm{p}<0.01$. Multiple regression analysis bearing on customers' retail store visit revealed that 'customer attitude', 'customer value' and 'store image' related factors 'service', 'shopping atmosphere', 'pricing', 'sales personnel competence', 'reliability', 'physical evidence', 'convenience' and 'after sales service' predicted 37.5 percentage $(\mathrm{R} 2=0.375)$ of customers' behavioral response (word-of-mouth communication) variability, $\mathrm{F}(16,377)=$ 13.500, however, 'merchandize', 'product innovation', 'location', crowding', 'product availability' and 'peripheral services' failed to show any significant relationship with customers' behavioral response (word-of-mouth communication). Thus, $\mathrm{H} 4$ was partially supported and $\mathrm{H} 5$, H6 were supported. 
Table 4: Regression Analysis of Store Image Facets on Retail Customers' Satisfaction and

Behavioral Response and Intentions

\begin{tabular}{|c|c|c|c|c|c|c|c|c|}
\hline \multirow[t]{2}{*}{ Predictors } & \multicolumn{2}{|c|}{$\begin{array}{l}\text { Customers' } \\
\text { Satisfaction } \\
\end{array}$} & \multicolumn{2}{|c|}{$\begin{array}{l}\text { Word-of-mouth } \\
\text { communications }\end{array}$} & \multicolumn{2}{|c|}{$\begin{array}{l}\begin{array}{l}\text { Intention to } \\
\text { switch }\end{array} \\
\end{array}$} & \multicolumn{2}{|c|}{$\begin{array}{l}\text { Loyalty } \\
\text { intention }\end{array}$} \\
\hline & $R$ & $\beta$ & $R$ & $\beta$ & $R$ & $\beta$ & $R$ & $\beta$ \\
\hline Store Image Facets & 0.521 & & 0.612 & & 0.268 & & 0.347 & \\
\hline Customer Attitude & & $0.35^{*}$ & & $0.51 *$ & & $-0.42 *$ & & $0.51 *$ \\
\hline Customer Value & & $0.32 *$ & & $0.26 *$ & & $-0.39 *$ & & $0.29 *$ \\
\hline Merchandize & & NS & & NS & & $-0.30 *$ & & $0.37 *$ \\
\hline Service & & NS & & $0.23 *$ & & NS & & NS \\
\hline $\begin{array}{l}\text { Shopping } \\
\text { Atmosphere }\end{array}$ & & $0.29 *$ & & $0.33^{*}$ & & NS & & NS \\
\hline Pricing & & $0.23^{*}$ & & $0.38 *$ & & $-0.28 *$ & & NS \\
\hline Product Innovation & & $0.22 *$ & & NS & & NS & & NS \\
\hline $\begin{array}{l}\text { Sales Personnel } \\
\text { Competence }\end{array}$ & & $0.34 *$ & & $0.27 *$ & & NS & & NS \\
\hline Reliability & & $0.26 *$ & & $0.35 *$ & & NS & & NS \\
\hline Physical Evidence & & $0.26 *$ & & 0.39* & & NS & & NS \\
\hline Convenience & & 0.31* & & $0.47 *$ & & $-0.31 *$ & & $0.24 *$ \\
\hline Location & & NS & & NS & & NS & & $0.36^{*}$ \\
\hline After Sale Service & & $0.25 *$ & & $0.32 *$ & & $-0.33^{*}$ & & $0.39 *$ \\
\hline Crowding & & NS & & NS & & $-0.22 *$ & & NS \\
\hline $\begin{array}{l}\text { Product } \\
\text { Availability }\end{array}$ & & NS & & NS & & $-0.27^{*}$ & & NS \\
\hline Peripheral Services & & NS & & NS & & NS & & NS \\
\hline $\mathbf{R}^{2}$ & & 0.271 & & 0.375 & & 0.072 & & 0.120 \\
\hline Adjusted R $^{2}$ & & 0.239 & & 0.347 & & 0.031 & & 0.081 \\
\hline $\begin{array}{l}\text { Overall model: } \\
\text { F }(\mathbf{1 6}, \mathbf{3 7 7}) \text { Ratio }\end{array}$ & 8.364 & & 13.500 & & 1.746 & & 3.068 & \\
\hline
\end{tabular}

Annotations: The dependent variables are customers' satisfaction and behavioral response and intentions; $* \mathrm{p} \leq .05 ;$ and $* * \mathrm{p} \leq .01$

Results of the third multiple regression analysis are also shown in table-4, the dependent variable was customers' intention to switch to other retail store and the customer attitude, customer value and store image as the independent variables. Like the first test, the overall model is significant at $\mathrm{p}<0.05$ or $\mathrm{p}<0.01$. Multiple regression analysis bearing on customers' retail store visit revealed that 'customer attitude', 'customer value' and 'store image' related factors 'merchandize', 'pricing', 'convenience', 'after sale services', 'crowing', and 'product availability' predicted 7.2 percentage $\left(\mathrm{R}^{2}=0.072\right)$ of customers' intention to switch variability, $F$ $(16,377)=1.746$, conversely, 'service', 'shopping atmosphere', 'product innovation', 'sales personnel competence', 'reliability', 'physical evidence', 'location' and 'peripheral services' failed to show any significant relationship with customers' intention to switch. Thus, $\mathrm{H}_{7}$ was partially supported and $\mathrm{H}_{8}, \mathrm{H}_{9}$ were supported. Results of the fourth multiple regressions are also shown in table-4, the dependent variable was customers' loyalty intention and the customer attitude, customer value and store image as the independent variables. Like the first test, the overall model is significant at $\mathrm{p}<0.05$ or $\mathrm{p}<0.01$. Multiple regression analysis bearing on customers' retail store visit revealed that 'customer attitude', 'customer value' and 'store image' 
related factors 'merchandize', 'convenience', 'location' and 'after sales service' predicted 12 percentage $\left(\mathrm{R}^{2}=0.120\right)$ of customers' loyalty intention variability, $F(16,377)=3.068$, however, 'service', 'shopping atmosphere', 'pricing', 'product innovation', 'sales personnel competence', 'reliability', 'physical evidence', 'crowding', 'product availability' and 'peripheral services' showed no significant relationship with customers' loyalty intention. Thus, $\mathrm{H}_{10}$ was partially supported and $\mathrm{H}_{11}, \mathrm{H}_{12}$ were supported.

\subsection{Hypotheses Testing: Multiple Regression Analysis Results of Customers' Satisfaction on Behavioral Response and Intentions (Table-5).}

Multiple linear regression analysis with forward selection was employed to predict customers' behavioral response and intentions from the customers' satisfaction. Three distinct multiple regression models were run to test the three hypotheses: one for behavioral response (word of mouth communication), one for intention to switch and one for loyalty intention. Table-5 shows results of the first multiple linear regression with customers' behavioral response (word of mouth communication) about the retail store as the dependent variable and the overall customers' satisfaction as the independent variable. The overall model is significant at $\mathrm{p}<0.05$ or $\mathrm{p}<0.01$. The overall model fit for regression equation was determined by $F$ statistics. The model revealed a significant impact of customers' satisfaction entered in the model. More specifically, overall customers' satisfaction accounted for 12.5 percentage $\left(\mathrm{R}^{2}=0.125\right)$ of variance in dependent variable of customers' behavioral response (word of mouth communication). $F(1,377)=$ 53.571, Thus, $\mathrm{H}_{13}$ was supported.

Table 5: Regression Analysis of Customers' Satisfaction on Behavioral Response and Intentions

\begin{tabular}{|l|l|l|l|l|l|l|}
\hline \multirow{2}{*}{ Predictor } & \multicolumn{2}{l|}{ Word-of-mouth communication } & \multicolumn{2}{l|}{ Intention to switch } & \multicolumn{2}{l|}{ Loyalty intention } \\
\cline { 2 - 7 } & $\boldsymbol{R}$ & $\boldsymbol{\beta}$ & $\boldsymbol{R}$ & $\boldsymbol{\beta}$ & $\boldsymbol{R}$ & $\boldsymbol{\beta}$ \\
\cline { 2 - 7 } & .353 & & -0.516 & & 0.297 & \\
\hline $\begin{array}{l}\text { Customers' } \\
\text { Satisfaction }\end{array}$ & & $\mathbf{0 . 4 1 *}$ & $\mathbf{- 0 . 3 6 *}$ & & $\mathbf{0 . 2 3 *}$ \\
\hline $\mathbf{R}^{\mathbf{2}}$ & & 0.125 & & 0.266 & & 0.088 \\
\hline Adjusted R & & 0.123 & & 0.264 & & 0.086 \\
\hline $\begin{array}{l}\text { Overall model: } \\
\text { F }(\mathbf{1}, \mathbf{3 7 7}) \text { Value }\end{array}$ & $\mathbf{5 3 . 5 7 1 * *}$ & $\mathbf{1 3 5 . 8 8 9 * *}$ & $\mathbf{3 6 . 1 8 4 * *}$ \\
\hline
\end{tabular}

Annotations: The dependent variables are behavioral response and intentions; ${ }^{*} \mathrm{p} \leq .05$; and ${ }^{* *} \mathrm{p} \leq .01$

Results of the second multiple linear regression are also shown in table-5. The dependent variable was customers' 'intention to switch' to other retail store and the overall customers' satisfaction was the independent variable. Like the first test, the overall model is significant at $\mathrm{p}$ $<0.05$ or $\mathrm{p}<0.01$. Multiple linear regression analysis bearing on customers' visit to retail store revealed that 'customers' satisfaction' predicted 26.6 percentage $\left(\mathrm{R}^{2}=0.266\right)$ of customers' intention to switch variability, $F(1,377)=135.889$, Thus, $\mathrm{H}_{14}$ was supported. Results of the third multiple linear regression are also shown in table-5. The dependent variable was customers' loyalty intention and the overall customers' satisfaction was the independent variable. Like the first test, the overall model is significant at $\mathrm{p}<0.05$ or $\mathrm{p}<0.01$. Multiple linear regression analysis bearing on customers' visit to retail store revealed that 'customers' satisfaction' predicted 8.8 percentage $\left(\mathrm{R}^{2}=0.088\right)$ of customers' loyalty intention variability, $F(1,377)=$ 
36.184, Thus, $\mathrm{H}_{15}$ was supported. Consequently, the customer satisfaction is excellent predictor of customers' behavioral response and intentions. This makes intuitive sense as the customer satisfaction with the store image is increasing, he/she is going to make more word of mouth communication and intention to switching on other store will decrease whereas possibility of loyalty of the customers to purchase from same retail store will also increase.

\section{Conclusion and Recommendations}

The results of the study have concluded into several points. First, out of three independent variables, customers' overall attitude towards retail store and customer value effect significantly on all the dependent variables (customers' satisfaction, behavioral response (word of mouth communication), intention to switch, and customers' loyalty intention), but impact of customers' overall attitude towards store is much stronger on word of mouth communication and loyalty intention, followed by customers' satisfaction and intention to switch, whereas the impact of customer value is more stronger on customers' satisfaction and intention to switch, followed by word of mouth communication and loyalty intention. It means that customers' overall attitude is an important factor in predicting word of mouth communication and loyalty intention, whereas perceived customer value is an important factor in predicting customers' satisfaction and their intention to switch to other retail store. Second, customers' satisfaction is formed through sales personnel competence, convenience, shopping atmosphere, reliability, physical evidence, after sales service, pricing and product innovation respectively and the results on the importance of sales personnel competence dimension in also in line with the work of King and Ring (1980) who found that sales associates play a critical role in achieving customer patronage and satisfaction. Third, word of mouth communication is directly affected most significantly by convenience, followed by physical evidence, pricing, reliability, store atmosphere, after sale service, sales personnel competence and service. Fourth, intention of retail customers' to switch on other store can be stopped by the store attributes such as: after sale service, followed by convenience, merchandize, pricing, product availability and crowding. Fifth, loyalty intention of customers' significantly affected by after sale service, followed by merchandize, location and convenience. Sixth, overall if we conclude the result of study in a composed manner convenience, after sale service and pricing are resulted as the factors which influenced the customers' satisfaction, behavioral response and intentions together. Furthermore shopping atmosphere, sales personnel competence, reliability and physical evidence are important factors in predicting customers' satisfaction and word of mouth communication; whereas merchandize effect significantly to behavioral intentions, location is important to predict loyalty intention only and product availability \& crowding are important predictors for intention to switch only, while peripheral services is not at all significant for customers' satisfaction, behavioral response and intentions. This makes intuitive sense since merchandize, its availability and peripheral services provided by retailers are general aspects and largely a given to most retail customers; they also assume location and crowding is beyond the control of retailers for all the customers. Literature has suggested that most of retailers have tendency to focus on the tangible attributes of the store (Theodoridis and Chatzipanagiotou, 2009). However, the present study has found intangible elements such as sales personnel competence, after sales service to be a significant contributor for customers' satisfaction, behaviour response and intentions. 
These results provide several important implications for the retailers as well as for the managers of retail stores in India, which must be taken care by them in their marketing strategies and plans. It is suggested that managers need to give greater attention on convenience (timing, home delievery of products, cashless transaction of shopping, multiple billing counters, convenient layout to make customers move easily around the store and to find products and other facilities conveniently and not to make shelves too high), after sale service such as implementing appropriate exchange and refund policy towards defective products, moreover appropriate prices, various offers and promotional scheme on products, so that retail store may compete with online retailers also. Store atmosphere, reliability, physical evidence and sales personnel competence factors are also taken on precedence basis by store manager so that customers can enjoy the shopping with pleasant shopping environment, trust and saving of time and efforts. Thus, marketers and store manager can promote a positive attitude, customers' satisfaction, word of mouth communication and loyalty intention through non-physical features of store, moreover by increasing perceived value of products and services through providing coupons, special promotion and appropriate prices of products and services. This study, however, has some limitations also. Since the present study was conducted with a limited sample of Delhi and Gurugram, the results cannot generalize to the entire metropolitan and smart cities in India. Future research should gather a sample of retail customers from various metropolitan and smart cities across the country in order to generalize the dimensions of store image as perceived by customers, customers overall attitude, perceived customer value and their effect on customers' satisfaction, customers' behavioral response (word of mouth communication), customers' intention to switch and customers' loyalty intention. Moreover future research might include the other environments settings such as food courts, restaurants, hotels industry and tourist places.

\section{References}

[1] Anderson, E.W. Fornell, C. and Lehman, D.R. Customer satisfaction, market share and profitability: findings from Sweden, Journal of Marketing, 58(3), 1994, 53-66.

[2] Anderson, E.W. Sullivan, M.W. The Antecedents and Consequences of Customer Satisfaction for Firms, Marketing Science, 12(2), 1993, 125-143.

[3] Andreassen, W. Lindestad, B. Customer loyalty and complex services: The impact of corporate image on quality, customer satisfaction and loyalty for customers with varying degrees of service expertise, International Journal of Service Industry Management, 9(1) 1998, 7-23.

[4] Anselmsson, J. Sources of Customer Satisfaction with Shopping Malls: A Comparative Study of Different Customer Segments, International Review of Retail, Distribution and Consumer Research, 16(1), 2006, 115-138.

[5] Baker, J. Parasuraman, A. Grewal. D. and Voss, G.B. The Influence of Multiple Store Environment Cues on Perceived Merchandise Value and Patronage Intentions, Journal of Marketing, 66, 2002, 120-141.

[6] Baltas, G. Papastathopoulou, P. Shopper characteristics, product and store choice criteria: a survey in the Greek grocery sector, International Journal of Retail and Distribution Management, 31(10), 2003, 498-507.

[7] Bielen, F. Demoulin, N. Waiting Time Influence on the Satisfaction-Loyalty Relationship in Services, Managing Service Quality, 17(2), 2007, 174-193.

[8] Bloemer, J. Odekerken-Schroder. G. Store Satisfaction and Store Loyalty Explained by Customer and Store-Related Factors, Journal of Consumer Satisfaction, Dissatisfaction and Complaining Behavior, 15, 2002, 68-80. 
[9] Bloemer, J. De-Ruyter, K. On the relationship between store image, store satisfaction and store loyalty, European Journal of Marketing, 32(5/6), 1998, 499-513.

[10] Carpenter, M.J. Moore, M. Consumer Demographics, Store Attributes, and Retail Format Choice in the US Grocery Market, International Journal of Retail and Distribution Management, 34(6), 2006, 434-52.

[11] Carroll, A. Barnes, S.J. Scornavacca, E. and Fletcher, K. Consumer perceptions and attitudes towards SMS advertising: recent evidence from New Zealand, International Journal of Advertising, 26(1), 2007, 79-98.

[12] Caruana, A. Money, A.H. and Berthon, P.R. Service quality and satisfaction-the moderating role of value, European Journal of Marketing, 34(11/12), 2000, 1338-1352.

[13] Chang, N. Fong. C. Green Product Quality, Green Corporate Image, Green Customer Satisfaction, and Green Customer Loyalty, African Journal of Business Management, 4(3), 2010, 2836-2844.

[14] Chang, C. Tu, C. Exploring Store Image and Customer Loyalty Relationship: Evidence from Taiwanese Hypermarket Industry, The Journal of American Academy of Business, Cambridge, 7(2), 2005, 197-205.

[15] Copeland, M. Relation of Consumers' Buying Habits to Marketing Methods, Harvard Business Review, 1, 1923, 282-289.

[16] Cronin, J.J. Taylor, S.A. Measuring service quality: a re-examination and extension, Journal of Marketing, 56(3), 1992, 55-68.

[17] Darian, J.C. Tucci, L.A. and Wiman, A.R. Perceived salesperson service attributes and retail patronage intentions, International Journal of Retail and Distribution Management, 29(5), 2001, 205-13.

[18] Day, G.S. A Two-Dimensional Concept of Brand Loyalty, Journal of Advertising Research, 9(3), 1969, 29-35.

[19] Demirgunes, B.K. The Antecedents of Store Image and Customer Satisfaction, International Journal of Research in Business and Social Science, 3(3), 2014, 48-62.

[20] Desai, K.K. Talukdar, D. Relationship between product groups' price perceptions, shoppers' basket size, and grocery store's overall store price image, Psychology and Marketing, 20(10), 2003, 903-933.

[21] Dick, A.S. Basu, K. Customer loyalty: toward an integrated conceptual framework, Journal of the Academy of Marketing Science, 22(2), 1994, 99-113.

[22] Doyle, P. Fenwick, I. Shopping habits in grocery chains, Journal of Retailing, 50(4), 1974, 39-52.

[23] Du-Preez, R. Visser, E. and Van-Noordwyk, H.J. Store Image: toward a Conceptual model, SA Journal of Industrial Psychology, 34(2), 2008, 50-58.

[24] Eroglu, S.A. Machleit, K. and Barr, T.F. Perceived retail crowding and shopping satisfaction: the role of shopping values, Journal of Business Research, 58(8), 2005, 1146-53.

[25] Fazlzadeh, A. Sahebalzamani, S. and Sarabi, B. Key Factors Affecting Customer Satisfaction With Iranian Retailer Stores: Evidence From Hypermarkets and Supermarkets, The IUP Journal of Marketing Management, 11(4), 2012, 7-33.

[26] Fornell, C. Johnson, M.D. Anderson, E.W. Cha, J. and Bryant, B.E. The American customer satisfaction index: nature, purpose, and findings, Journal of Marketing, 60, 1996, 7-18.

[27] Fox, E.J. Montgomery, A.L. and Lodish, L.M. Consumer shopping and spending across retail formats, Journal of Business, 77(2), 2004, 25-60.

[28] Groeppel-Klein, A. Germelmann, C.C. Mind the mall: do we remember what we see?, Advances in Consumer Research, 30, 2003, 56-67.

[29] Helgesen, O. Havold, J.I. and Nesset, E. Impacts of store and chain on the "quality-satisfactionloyalty process" in petrol retailing, Journal of Retailing and Consumer Services, 17, 2010, 109118. 
[30] James, D.L. Durand, R.M. and Dreves, R.A. The use of a multi-attributes attitudes model in a store image study, Journal of Retailing, 52, 1976, 23-32.

[31] Juhl, H.J. Kristensen, K. and Ostergaard, P. Customer satisfaction in European food retailing, Journal of Retailing and Consumer Services, 9(6), 2002, 327-34.

[32] King, C.W. Ring, L.J. Market positioning across retail fashion institutions: a comparative analysis of store types, Journal of Retail, 56(1), 1980, 37-55.

[33] Koo, D. Inter-relationships among Store Images, Store Satisfaction and Store Loyalty among Korea Discount Retail Patrons, Asia Pacific Journal of Marketing and Logistics, 15(4), 2003, 4271.

[34] Lindquist, J.D. Meaning of image Q survey of empirical and hypothetical evidence, Journal of Retailing, 50(4), 1974, 29-38.

[35] Marks, R.B. Operationalising the concept of store image, Journal of Retailing, 52, 1976, 37-46.

[36] Martineau, P. The personality of the retail store, Harvard Business Review, 36(1), 1958, 47-56.

[37] McDougall, G.H.G. Levesque, T.J. Customer satisfaction with services: putting perceived value into the equation", Journal of Services Marketing, 14(5), 2000, 392-410.

[38] Morschett, D. Swoboda, B. and Foscht, T. Perception of store attributes and overall attitude towards grocery retailers: the role of shopping motives, International Review of Retail Distribution and Consumer Research, 15(4), 2005, 423-47.

[39] Naderian, A. Study of Store Image Attributes Effect on Customer Satisfaction among Malaysian Customers, International Journal of Maketing \& Business Communication, 1(3), 2012, 1-10.

[40] Nunnally, J.C. Psychometric Theory, Second Edition, McGraw Hill, New York, 1978.

[41] Oliver, R.L. A cognitive model of the antecedents and consequences of satisfaction decisions, Journal of Marketing Research, 17(November), 1980, 460-69.

[42] Olsen, S.O. Comparative evaluation and the relationship between quality, satisfaction, and repurchase loyalty, Journal of the Academy of Marketing Science, 30(3), 2002, 240-49.

[43] Pan, Y. Zinkhan, G. Determinants of retail patronage: a meta-analytical perspective, Journal of Retailing, 82(3), 2006, 229-43.

[44] Parasuraman, A. Grewal, D. The impact of technology on the quality-value-loyalty chain: A research agenda, Journal of the Academy of Marketing Science, 28(1), 2000, 168-175.

[45] Rauyruen, P. Miller, K.E. Relationship quality as a predictor of B2B customer loyalty. Journal of Business Research, 60(1), 2007, 21-31.

[46] Samli, A.C. Kelly, J.P. and Hunt, H.K. Improving the Retail Performance By Contrasting Management And Customer-Perceived Store Image: A Diagnostic Tool For Corrective Action, Journal of Business Research, 43, 1998, 27-38.

[47] Sweeney, J.C. Soutar, G.N. Consumer perceived value: The development of a multiple item scale, Journal of Retailing, 77(2), 2001, 203-220.

[48] Theodoridis, P.K. Chatzipanagioutou, K.C. Store Image Attributes and Customer Satisfaction across Different Customer Profiles within the Supermarket Sector in Greece, European Journal of Marketing, 43(5/6), 2009, 708-734.

[49] Thomas, S. Linking customer loyalty to customer satisfaction and store image: a structural model for retail stores, Decision, 40(1/2), 2013, 15-25.

[50] Tse, D.K. Wilton, P.C. Models of consumer satisfaction formation: an extension. Journal of Marketing Research, 25(2), 1988, 204-212.

[51] Turhan, G. Building Store Satisfaction Centred on Customer Retention in Clothing Retailing: Store Design and Ease of Shopping, International Journal of Research in Business and Social Science, 3(1), 2014, 89-105.

[52] Tuu, H.H. Olsen, S.O. and Linh, P.T.T. The moderator effects of perceived risk, objective knowledge and certainty in the satisfaction-loyalty relationship, Journal of Consumer Marketing, 28(5), 2011, 363-375. 
[53] Watanabe, E.A.M. Lima-Filho, D.O. and Torres, C.V. Store Image Attributes and Customer in Satisfaction Supermarkets in Campo Grande-Ms, Revista Brasileira de Marketing, 12(4), 2013, 85-107.

[54] Yoo, S.J. Chang, J.Y. An Exploratory Research on The Store Image Attributes Affecting Its Store Loyalty, Seoul Journal of Business, 11(1), 2005, 19-41.

[55] Yoon, Y. Lee, J. and Lee, C. Measuring festival quality and value affecting visitors' satisfaction and loyalty using a structural approach, International Journal of Hospitality Management, 29, 2010, 335-342.

[56] Zeithmal, V.A. Consumer perception of price, quality and value. A means-end model and synthesis of evidence, Journal of Marketing, 52(July), 1988, 2-22.

[57] Zeithaml, V.A. Service quality, profitability, and the economic worth of customers: what we know and what we need to learn, Journal of the Academy of Marketing Science, 28(1), 2000, 67-85.

[58] Zeithaml, V.A. Berry, L.L. and Parasuraman, A. The behavioral consequences of service quality, Journal of Marketing, 60(2), 1996, 31-46.

*Corresponding author.

E-mail address: pankaj3950@yahoo.co.in 